\title{
The English Language Teaching in Andhra Pradesh should meet the requirements of the present Global World
}

\author{
Dr. I. Suresh ${ }^{1}$, V. Govardhanarao ${ }^{2}$, T. Bhavani sankar ${ }^{3}$, Dr. B. Ramanuja \\ Srinivas $^{4}$
}

\author{
${ }^{1}$ Associate Professor, St. Mary's Group of Institutions, Guntur, India \\ ${ }^{1,2}$ Assistant Profes sor, St. Mary's Group of Institutions, Guntur, India \\ ${ }^{3}$ Profes sor, St. Mary's Group of Institutions, Guntur, India
}

\begin{abstract}
This paper throws light on the status of language learning in Andhra Pradesh and draw backs, problems and education system in the state. It tries to reveal the practical difficulties in teaching English language at school level. The paper focuses on a shift from medium of instruction in the state government schools and a change that occurred in the system since then. It suggests utilizing the resources that are available for rectifying the problems in order to meet the requirements of the present situation globally by the learners.
\end{abstract}

Keywords - third language, mother tongue, regional medium, communication skills, English, foreign language.

\section{INTRODUCTION}

The most common language spoken in India after Hindi is English. It is estimated approximately that 120 millions of Indians speak English today. English is known the world's lingua franca at present global scenario. There are several regional languages existed in India and Hindi being a common spoken language by the people. The southern states of India have regional languages as their first languages and Hindi as a second language whereas English is a third language. In the state of Andhra Pradesh, Telugu is the mother tongue of the people as well existed as a regional language of the state. English is considered as the first language in schools which have English as a Medium of instruction whereas it is prescribed as a third language for the Telugu Medium schools.

Students who ever possess communication skills and fluency in English are placed in good positions and they have constant career growth and financially better in their lives. Vie wing this factor parents intend to get their child ren educated in English Medium. This situation has been occurred since the year 2000 in Andhra Pradesh.

\section{Education svstem in Andhra Pradesh:}

Education in the state at Government schools consists of Primary and Secondary levels whereas teachers are recruited specially for both the levels. In private schools the education starts from Pre-Primary, Primary and High School whereas it is totally shows difference with corporate schools. Education in those schools starts from Kinder Garden to tenth standard. These are highly attracted by the all categories of people in the state. Irrespective of economical status they want to send their children to these corporate schools. The main reason for this is too simple to mention that the whole environment and education of these schools exists English as a medium of instruction and create an atmosphere of making students converse in English.

English is the first language in private and corporate schools according to academics and such priority is given for even communicative English. There is a special focus on students to communicate in English apart from their regular studies. The situation is quiet different in the Government schools where the education continuously goes in the regional language that feels the students home. It is academically brought achievements at the end of the academic year and students excel at the final examinations. It leads to possess a certificate with good marks or grade on the contrary students may not have ability to compete with the global market.

Government of Andhra Pradesh has introduced English medium in state government schools since the year 2000 initially with sixth standard. Students are given choice either to be instructed in any medium. It has brought change in the education system.

\section{Curriculum followed by the schools in the state:}

The curriculum in the government schools is according to SCERT whereas in private and corporate schools follow 
NCERT, some of them CBSE and others follow ICSE. The curriculum has lot of impact on teaching as well language development among the students. It is the responsibility of the curriculum to lay emphasis on language learning. SCERT gives equal priority for all the subjects for learning and NCERT simplifies the subjects to the levels of the learner and convince the learners feel easy. Both the syllabi deal with state and national levels. It treats all the learners equal though there are lots of parities in learning.

In case of the later type of schools follow CBSE and ICSE prioritize Eng lish language to the extent since lower classes. Students are introduced to English language through different books and number of activities apart from other subjects. It gives learners a wider scope to learn language in many ways. The learning process has continuity till they complete schooling.

Problems in teaching English Language at school level in Andhra Pradesh:

Most of the Southern Sates in India are bound up to teach in regional language even lessons, prose and poetry of Eng lish was also translated into regional language. In this circumstance, students couldn't acquire language skills. It has become unaccomplished dream for them. Previously, English is treated as one of the academic subjects to be scored in order to promote to the next class. In this criterion, students couldn't meet the demands of the present global market

The schools mostly located in the rural and remote villages are far from the culture of the urban society. Teachers whoever are recruited in these schools by the government of the state generally teach students for the sake of complet ion of the academic year.L2 is not much given importance to teach as a communicative language. This leads to trouble the student in his future and he completely lose interest in learning language.

\section{Major draw backs of teaching English language at school} levels:

There are many reasons contribute for these draw backs have been taking place from many years. The unchanged curriculum is one of the draw backs which impact the students' general and academic learning. Though there is a considerable significance to learn English language to connect with the world yet the curriculum is not changed according to the needs of the present days and still it has been experimenting at some other level by the committees whichever appointed by the state government to prepare curriculum for government schools.

Lack of teacher training programs in also another major drawback that effect teaching as well learning. It leads to monotonous teaching and learning. Learners neither pay attention nor put concentration if the teacher lacks skills in teaching creatively. Teachers have to be updated with the latest methodology from time to time as it is necessary for the present scenario. Government has to provide some basic training classes in language learning occasionally for the teachers to enhance their knowledge and teaching skills. And also the government has to make it mandatory that the teachers whoever have to be recruited in the private and corporate schools should be trained and choosy for teaching.

Learning and teaching language go hand in hand which requires lot of resources. Lack of providing resources is also a drawback of language teaching in the state. Training programs, activities, competitions and audio video aids are said to be primary resources in schools. Though some of the schools have been providing these, there isn't expected result from the students.

It is clear that time constraint is also another drawback of language learning. The time table in corporate schools obviously concentrates on Mathematics, Physics, Che mistry and social studies. Languages are prescribed for the sake of scoring marks. This narrow approach makes the learners far from acquiring English language.

Translation and Grammar methods of approach in teaching add to one more draw backs in learning language. Teachers teach students in regional language even the basics of the grammar and old translation methods from English language make the learner scared of acquiring a language. It would be certainly a Greek and Latin to the learners. Language learning becomes complex with these approaches.

References of learning language from various corners of the world are not being taken place in the education system. Sharing experiences, exchanging ideas and learning from others should be done in every step of the schooling through educational tours, interstate competitions and guest lectures.

\section{CONCLUSION}

In view of the above problems and draw backs mentioned regarding learning a language as well measurements to be taken up to rectify the problems may bring fruitful result in equipping English language by the learners.

There are various institutions worldwide which offer English training classes and courses as well. If the Government takes a further step to train the teachers into enrolling into these courses will have multi benefits, changes in the curriculum and sufficient time allotted in the time table may bring better English language teaching and it definitely lead to meet the requirements of the present world. 


\section{REFERENCES}

[1] Robert, J. (2006) Simple Tools \& Techniques of PEST analysis. Sydney: Pearson Group Publications.

[2] Edward, L., (2000). Economic and Social Analysis, London: John Wiley \& Sons Profes sional Publications.

\section{Web References}

[4] https://www. Shodhaganga.inflibnet.ac.in/

[5] https://en.m.wikipedia.org 